\title{
LONG TIME SERIES OF LANDSAT IMAGES TO RECONSTRUCT RIVER SURFACE TEMPERATURE AND TURBIDITY REGIMES OF GUADALQUIVIR ESTUARY
}

\author{
Ricardo Díaz-Delgado ${ }^{1}$, Iban Ameztoy ${ }^{1}$, Jordi Cristóbal ${ }^{2}$ and Javier Bustamante ${ }^{l}$ \\ 1 Remote Sensing and GIS Laboratory of Doñana Biological Station-CSIC. Seville. Spain \\ 2 Department of Geography, Autonomous University of Barcelona, Cerdanyola del Vallès, Spain.
}

\begin{abstract}
In the last century the Guadalquivir River in Andalusia has been dramatically transformed affecting its ecological and hydrological functioning. In view of a new dredging plan to increase ship size and number arriving to Seville, a research consortium has started to study the state of the Guadalquivir Estuary. The Remote Sensing and GIS laboratory of Doñana Biological Station participates in the project with the aim to reconstruct the last 35 years regime of turbidity and river surface temperature (RST), both parameters revealing the estuarine response to natural and human-driven dynamics. Based on a long time series of Landsat images (TM and $\mathrm{ETM}+$ ), we have developed accurate methods to systematically map RST and turbidity gradients across the last $100 \mathrm{~km}$ stretch of the River.

We present the results of applying an empirical model for river turbidity mapping and a physical model to map RST by using optical and thermal bands of TM and ETM + sensors. Both models were validated with ground-truth data and are used to reconstruct the historical dynamics of the Guadalquivir Estuary.
\end{abstract}

Index Terms - Turbidity, River Surface Temperature, Estuary, Landsat, Historical Reconstruction.

\section{INTRODUCTION}

Guadalquivir is one of the longest rivers in the Iberian Peninsula and so, it provides all the services needed by the whole Andalusian region (Southern Spain). More than 2000 yrs of use has attributed to the river a major cultural and socioeconomic role. In the last century, the river has undergone the most dramatic transformations and consequently its ecological and hydrological functioning has been seriously affected. Extensive cut-offs, dredging and channeling largely modified the final stretch of the river [1]. Nowadays, fisheries, rice paddles, waterway traffic, irrigated crops, fish farms, among the most demanding uses are the main pressures over the Guadalquivir Estuary. Such disturbances come from the continuous demand of fresh water to retain tidal influence through regulatory dams and periodical labor to keep ship canal depth. Recently, a deeper dredge has been proposed to increase ship size and number entering the Seville harbor.

Under this framework, a consortium of scientific institutions has started an integrative research project to understand the hydrological and ecological status of the Guadalquivir Estuary and evaluate the effects of the various pressures on its natural functioning and services.

The Remote Sensing and GIS laboratory of Doñana Biological Station participates in the project with the aim to reconstruct the last 35 years regime of turbidity and river surface temperature (RST), both parameters revealing the estuarine response to natural and human-driven dynamics. Based on a long time series of Landsat images (TM and ETM+), we have developed accurate methods to systematically map RST and turbidity gradients across the last $100 \mathrm{~km}$ stretch of the River, i.e. the Estuary.

In this paper we present the results of applying an empirical model for River turbidity mapping and a physical model to map RST by the use of the optical and thermal bands of TM and ETM + sensors aboard of Landsat satellites. Both models were validated with ground-truth data and are used to reconstruct the recent historical dynamics of the Guadalquivir Estuary. Time series and anomaly analyses were then applied in order to identify trends and temporal patterns allowing to interpret ecological and hydrological functioning of the Guadalquivir Estuary.

\section{MATERIAL AND METHODS}

A network of probes and gauges were installed in 2008 by the consortium along the estuary to systematically record river flow measurements, together with temperature, salinity, and turbidity. In addition, the Andalusian Environment Agency carries out since 2006 periodical water sampling along the River measuring several physicochemical parameters, including nephelometric water turbidity and Suspended Sediments Concentration (SSC). We also measured periodically both in situ turbidity (since 2003) and in transects aboard of a ship (since 2008). This valuable and substantial ground-truth information was used to validate the RST and turbidity mapping for every single scene coincident with sampling days. 
The available data used is a long time series of more than 300 Landsat scenes (path 202, row 34) geometric and radiommetricaly corrected. The time series processing consist of metadata retrieval, automatic co-registration of every scene to a single geometrically corrected ETM+ panchromatic scene (independent RMS test value $<15 \mathrm{~m}$ ) and radiommetric correction with the use of a Lambertian simple dark object model [2]. Finally, radiommetric normalization is carried out in order to allow consistency of time series analysis by using pseudo-invariant areas and cloud cover masking [3] [4].

Models were applied to a River mask calculated by using a segmentation approach.

\subsection{River surface emissivity ( $\varepsilon w)$}

There are several techniques to compute land surface emissivity using Landsat data [5] [6]. However, these methodologies are developed for soil and vegetation covers and are not useful in the case of water. For this reason, we have decided to assign a $\varepsilon_{w}$ value of 0.99 . This value has been extracted from the ASTER Spectral Library (http://speclib.jpl.nasa.gov/search-1) using different water signatures. Although is likely that $\varepsilon_{w}$ changes with turbidity, no previous studies have reported such variation.

\subsection{River Surface Temperature retrieval}

To estimate RST we use thermal band $6(10.40-12.50 \mu \mathrm{m})$ of Landsat TM and ETM+ together with MODIS water vapor product (MOD05), a constant emissivity value for water, and air temperature at the time of Landsat scene acquisition. Daily water vapor TERRA/AQUA MODIS product (MOD09) to atmospherically correct Landsat images and obtain water surface temperature were downloaded from the EOS Gateway (http://edcimswww.cr.usgs.gov/pub/imswelcome/).

Land and water surface temperature has been carried out using the methodology proposed by Cristóbal et al. [7] which is based in the radiative transfer equation. Its main advantage is the independence on radiosonde data for land and water surface temperature retrieval. The methodology is designed to obtain the land and water surface temperature in global conditions used in the development of this algorithm based in TIGR-TOVS radiosonde database, representative of the majority of atmospheric conditions at a global scale. The algorithm is designed for wide range of water vapor

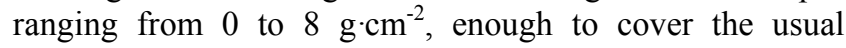
conditions in the Iberian Peninsula.

The first step converts digital numbers of band 6 to radiances using the calibration coefficients of TM and ETM+. MOD05_L2 product is processed to remove the "bow-tie" effect [8]. The algorithm for RST estimation is the following:

$$
T_{s}=\gamma\left[\frac{1}{\varepsilon}\left(\psi_{1} L_{\text {sen }}+\psi_{2}\right)+\psi_{3}\right]+\delta
$$

where $L_{\text {sen }}$ is the at sensor radiance, $\varepsilon$ is the constant emissivity for water, $\psi$ are atmospheric functions calculated from the MODIS water vapor product $\gamma$ and $\delta$ are parameters estimated as follows:

$$
\gamma \approx \frac{\mathrm{T}_{\mathrm{sen}}^{2}}{\mathrm{~b}_{\gamma} \mathrm{L}_{\mathrm{sen}}} \quad \delta \approx \mathrm{T}_{\mathrm{sen}}-\frac{\mathrm{T}_{\mathrm{sen}}^{2}}{\mathrm{~b}_{\gamma}}
$$

using the brightness temperature, $\mathrm{T}_{\text {sen }}$, calculated following the inversion of Planck law:

$$
T_{\text {sensor }}=\frac{\mathrm{K} 2}{\ln (\mathrm{K} 1 / \mathrm{L} \lambda+1)}
$$

according to Landsat 4, 5 and 7 calibration constants shown in table 1 .

Table 1. Calibration constants used to estimate Tsensor

\begin{tabular}{|l|c|c|}
\cline { 2 - 3 } \multicolumn{1}{c|}{ Sensor } & K1 & K2 \\
\hline Landsat-4 TM & 671.62 & 1284.30 \\
\hline Landsat-5 TM & 607.76 & 1260.60 \\
\hline $\begin{array}{l}\text { Landsat-7 } \\
\text { ETM+ }\end{array}$ & 666.09 & 1282.70 \\
\hline
\end{tabular}

\subsection{River Turbidity and SSC models}

For water turbidity mapping we applied Generalized Additive Models (GAM) to extract the best predictor of measured Nephelometric Turbidity Units (NTU) and Suspended Sediments Concentration in $\mathrm{mg} / \mathrm{l}$ (SSC). TM visible bands have been shown to be the most explicative predictors for water turbidity [9]. Ground-truth positions were crossed by buffering locations $50 \mathrm{~m}$ around, ranking the values from 5 to 8000 NTUs. Predictor bands entered the model in reflectance values. We not only entered simple bands but we also tried many different ratios such as $\mathrm{B} 1 / \mathrm{B} 2$, $\mathrm{B} 2 / \mathrm{B} 3, \mathrm{~B} 1 / \mathrm{B} 4, \mathrm{~B} 2 / \mathrm{B} 4, \mathrm{~B} 3 / \mathrm{B} 4$ and $(\mathrm{B} 1+\mathrm{B} 2+\mathrm{B} 3) / 3 * \mathrm{~B} 4$. NTU entered the model as the response value logarithmically transformed much more suitable for the statistical procedure.

\subsection{Time series analysis}

Once produced, turbidity and RST maps were analyzed to identify episodic events affecting estuarine dynamics as well as to detect trends through Man-Kendall time series test in order to evaluate the effects of human pressures on the natural dynamics of the river. Also, anomalies 
(difference with historical average values) were calculated seeking to identify temporal and spatial patterns of RST.

\section{RESULTS AND DISCUSSION}

\subsection{River Surface Temperature mapping}

RST maps were obtained by systematically applying the Cristóbal et al. [7] model to every single Landsat scene (117 images) for which there was available MOD05 data, i.e. the 2000-2009 period. For few cases, output had to be revised due to low altitude clouds and fogs.

Average temperature varied along the year from 10 to $27^{\circ} \mathrm{C}$ (Figure 1). However, RST range was spatially smoothed along the Estuary (Figure 2).

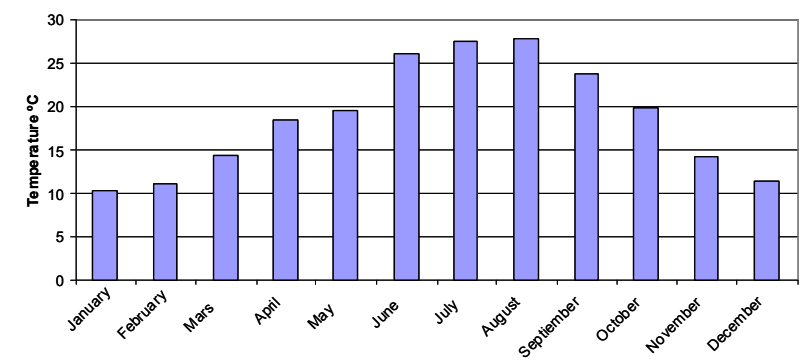

Figure 1. Monthly average temperature of the Guadalquivir River as estimated through RST retrieval for the last 9 years.

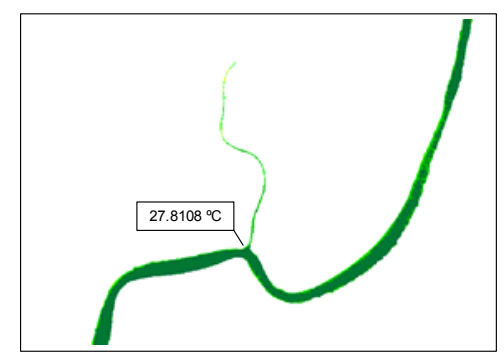

Figure 2. Quicklook of RST map produced for Landsat scene dated from August the 3d, 2003.

\subsection{River Turbidity and SSC mapping}

For turbidity and SSC the visible spectrum is the most informative from which TM/ETM+ band $3(0.63-0.69 \mu \mathrm{m})$ is the most contributive band explaining up to $75 \%$ of deviance in comparison to NTU and SSC ground-truth measurements and shows lineal relationship (Figure 3).

Both models were applied over 217 images covering the 1984-2009 period. Most of the available Landsat scenes were acquired in summer. Despite this caveat, 25 year average reveals special turbid period during winter due to the usual increase on River discharge (Figure 4).

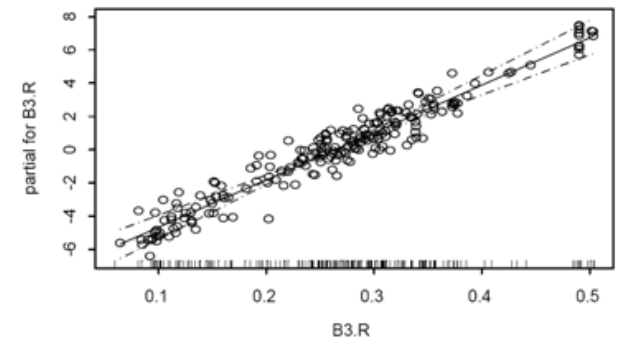

Figure 3. Lineal partial relationship between NTU and $\mathrm{TM} / \mathrm{ETM}+$ band 3 reflectance.

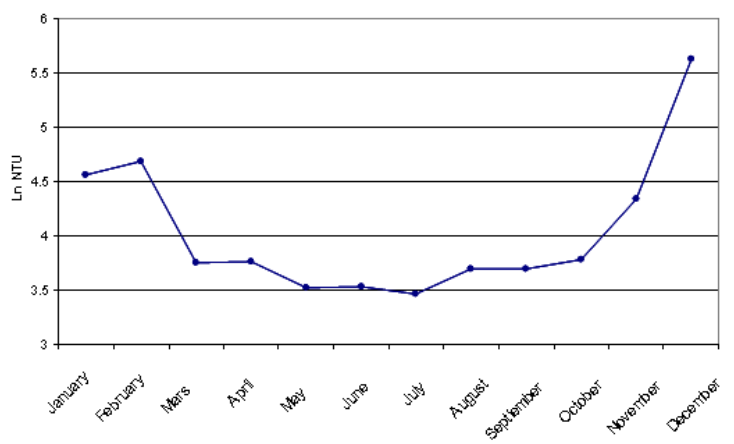

Figure 4. Monthly average ln NTU values in the Guadalquivir River for the last 25 years.

Spatial profiles along the Estuary reveal the decreasing gradient until the mouth of the River where SSC become dissolved in the ocean (Figure 5).

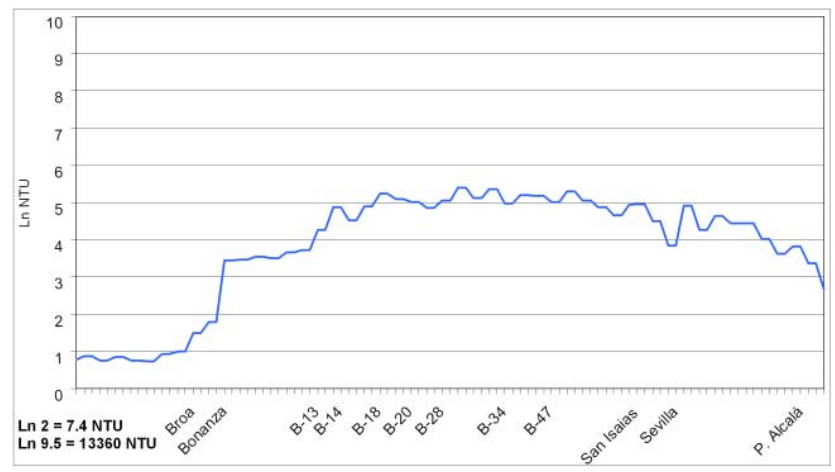

Figure 5. Spatial profile of $\ln$ NTU values every $2.7 \mathrm{~km}$ from the mouth (left side of the graphic) of Gualdaquivir River to the $1^{\text {st }}$ reservoir close to Seville city (right side) for a single scene dated from August the $11^{\text {th }}, 2008$.

\subsection{Time series and anomaly analyses}

Once produced, turbidity and RST maps were used to evaluate average historical trends. For turbidity, we may easily distinguish one regular period from 1984 to 2000, where the River shows regular oscillations mainly linked to rainfall and discharge. It is starting from the year 2000 when the River begun to undergo episodic turbid events (Figure 6). 


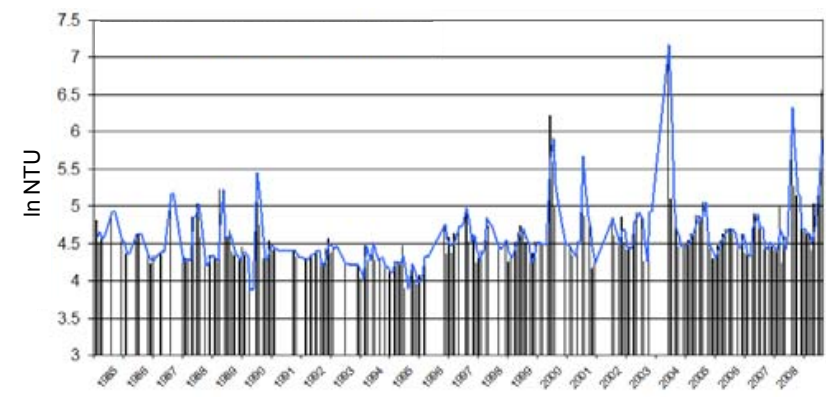

Figure 6. Temporal profile of $\ln$ NTU values in the last 25 years averaged for the Guadalquivir Estuary.

On the other hand, RST reveal a relative regular temporal pattern with slight disturbances during the last 2 years linked to turbid events (Figure 7).

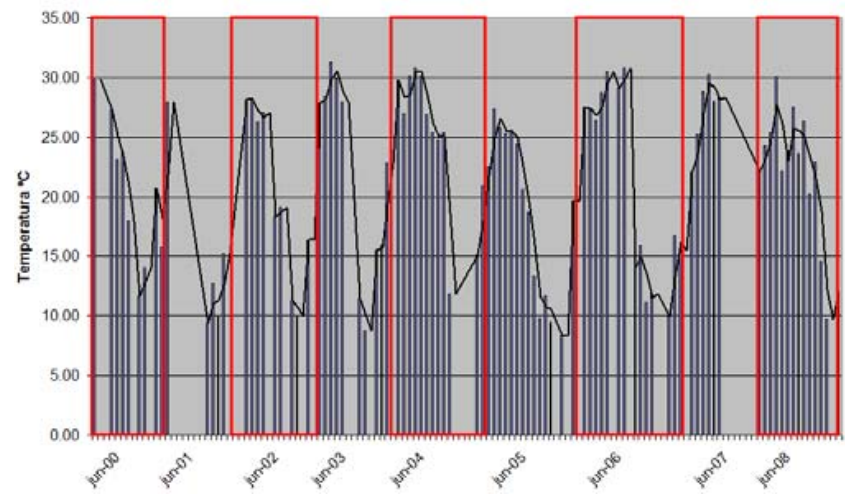

Figure 7. Temporal profile of RST values in the last 9 years averaged for the Guadalquivir Estuary.

\section{CONCLUSIONS}

The use of remote sensing images to map River turbidity and River Surface Temperature has allowed to reconstruct the historical temporal and spatial patterns and assess about the major recent changes in turbidity regime for the Guadalquivir Estuary.

The developed methods have been proved successful when compared to ground-truth data. However, radiometric temperature has still to be measured in situ in order to check differences between RST and water thermal temperature.

Guadalquivir Estuary shows important changes in its recent historical functioning when assessed through RST and turbidity trend analysis, probably due to dramatic modifications of the natural ocean-river exchange regime.

\section{REFERENCES}

[1] Fernández-Delgado, C., P. Drake, A.M. Arias, and D. GarcíaGonzález. Peces de Doñana y su entorno, Ministerio de Medio Ambiente, Madrid, 2000.

[2] Pons, X. and Solé-Sugrañes, L. "A simple radiometric correction model to improve automatic mapping of vegetation from multispectral satellite data," Remote Sensing of Environment 48:191-204, Elsevier, 1994.

[3] Díaz-Delgado, R., Bustamante, J., Aragonés, D. and Pacios, F. "Determining water body characteristics of Doñana shallow marshes through remote sensing". In Proceedings of the 2006 IEEE International Geoscience \& Remote Sensing Symposium \& 27th Canadian Symposium on Remote Sensing Pp: 3662-3664. (IGARSS2006), organised by the Geoscience and Remote Sensing Society. Denver, Colorado, 31st July-4 August 2006.

[4] Aragonés, D., Díaz-Delgado, R. and Bustamante, J. "Estudio de la dinámica de inundación histórica de las marismas de Doñana a partir de una serie temporal larga de imágenes Landsat". In Teledetección: Avances en la observación de la Tierra, Eds. M. Arbelo, A. González and J.C. Pérez. Proceedings of the XI Congreso Nacional de Teledetección organized by AET, Pp. 407410, Tenerife, 21-23 September. 2005.

[5] Sobrino, J. A. and N. Raissouni. Toward remote sensing methods for land conver dynamic monitoring: application to Moroco, International Journal Remote Sensing, 21 (2): 353-366, 2000 .

[6] Valor, E and V. Caselles. "Validation of the vegetation cover method for land surface emissivity estimation", In Recent Research Developments in Thermal Remote Sensing, edited by V. Caselles, E. Valor, and C. Coll pp. 1-20, Research Signpost, Kerala, India. 2005.

[7] Cristóbal, J. J. C. Jiménez-Muñoz J. A. Sobrino M. Ninyerola and Pons, $\mathrm{X}$. "Improvements in land surface temperature retrieval from the Landsat series thermal band using water vapor and air temperature". Journal of Geophysical Research, 114, D08103, 116, 2009.

[8] Wen, X. "A new prompt algorithm for removing the bowtie effect of MODIS L1b data". The International Archives of the Photogrammetry, Remote Sensing and Spatial Information Sciences, Vol. XXXVII. Part B3b, pp. 5-10, Beijing, 2008

[9] Bustamante, J., Pacios, F., Díaz-Delgado R. and Aragonés, D. "Predictive models of turbidity and water depth in the Doñana marshes using Landsat TM and ETM+ images", Journal of Environmental Management. 90:2219-2225, 2009. 